\title{
Estimation of fuel loads and carbon stocks of forest floor in endemic Dalmatian black pine forests
}

\author{
Nera Bakšić, \\ Darko Bakšić
}

\section{Introduction}

The forest floor, also known as the $\mathrm{O}$ horizon of the soil profile, consists of organic matter in various states of decomposition that has accumulated on the surface of either mineral or organic soil. It links en ergy flow and nutrient cycling between living vegetation and soil in forest ecosys tems. It supports a tremendous biodiversity of microflora and fauna that drive de composition, humification and mineralisation (Letang \& De Groot 2012). The forest floor helps determine the physical, chemical and microbiological properties of soil, and it helps reduce soil erosion, sequester

$\square$ University of Zagreb, Faculty of Forestry, Svetošimunska cesta 23, 10002 Zagreb (Croatia)

@ Darko Bakšić (dbaksic@sumfak.hr)

Received: Jul 04, 2019 - Accepted: Jun 27, 2020

Citation: Bakšić N, Bakšić D (2020). Estimation of fuel loads and carbon stocks of forest floor in endemic Dalmatian black pine forests. iForest 13: 382-388. - doi: 10.3832/ifor3184-013 [online 2020-09-01]

Communicated by: Rossella Guerrieri

Estimation of forest floor loading is important for many forest management applications, especially those related to fire management and carbon balance. We quantified the physical properties (depth, fuel load, bulk density) and carbon stocks of endemic Dalmatian black pine (Pinus nigra J.F. Arnold subsp. dalmatica [Vis.] Franco) forest floor layers. We also examined how these properties differ with stand age and layer. Forest floor depths ranged from $1.5 \mathrm{~cm}$ to $11.5 \mathrm{~cm}$ and forest floor fuel (FFF) loads ranged from $11.9 \mathrm{Mg} \mathrm{ha}^{-1}$ in the young stand to $197.3 \mathrm{Mg} \mathrm{ha}^{-1}$ in the old stand. Forest floor carbon (FFC) stocks ranged from $6.4 \mathrm{Mg} \mathrm{C} \mathrm{ha}^{-1}$ in the young stand to $85.8 \mathrm{Mg} \mathrm{C} \mathrm{ha}^{-1}$ in the old stand. We developed regression equations that can be used to convert the investigated forest floor depth into load in each layer individually and across all layers. These equations, together with the organic carbon $(O C)$ concentration de termined here for individual forest floor layers, simplify quantification of carbon stocks in the forest floor. Bulk density (BD) values reported here can also be used to convert depth measurements to loads for each layer and the entire forest floor. The results presented here are suitable for rapid estimation of FFF loads and FFC stocks based solely on forest floor depth, without the need to sample and analyze large amounts of forest floor fuels. Similarly, spatial distribution in FFF loads and carbon stocks can be assessed simply by measuring forest floor depths.

Keywords: Dalmatian Black Pine, Forest Floor, Fuel Load, Carbon Stock, Bulk Density

forest carbon as well as promote ecosystem resilience and vegetation reproduction (Baldock \& Nelson 2000, Berg \& McClaugherty 2014).

The forest floor is generally divided into three layers depending on the degree of decomposition, which differ from one another by their chemical and physical properties (Miyanishi 2001, Varner 2005, Banwell \& Varner 2014, Berg \& McClaugherty 2014). The litter layer (L) or Oi is the uppermost layer and consists of unaltered, recently deposited organic matter such as leaves, needles, twigs, moss and lichens. The origin of the material is easily identifiable. Underlying this is the fermentation layer (F) or Oe, which consists of discoloured, fragmented, partially decomposed but still recognisable organic matter. The $\mathrm{F}$ layer has a higher bulk density (BD) and mineral content than the L layer. The deepest layer is humus $(\mathrm{H})$ or $\mathrm{Oa}$, which consists of dark, unrecognisable, well-decomposed organic matter. It has even greater $\mathrm{BD}$ and mineral content than the $\mathrm{F}$ layer (Hood 2010, Banwell et al. 2013).

Characterising forest floor layers is important for many forest management applications, especially those related to fire management and carbon balance (Van Wagner 1987, Ottmar et al. 2007, De Groot 2012, Lutes 2017). Forest floor fuel (FFF) loading (or mass) is one of the most important properties of the forest floor for pre- scribed fire planning, fire behavior prediction, fuel modelling and carbon stock calculations (Chojnacky et al. 2009, De Groot et al. 2009, Letang \& De Groot 2012, Keane 2015). For example, loading measurements are critical for estimating fuel consumption in wildland fires and for predicting their ecosystem effects, including emissions of smoke and carbon as well as tree mortality (Ottmar \& Andreu 2007). Information on FFF load is particularly important because the consumption of this layer of forest fuel varies widely and is the greatest source of uncertainty in estimating total carbon emissions during fires (De Groot et al. 2009).

The different chemical and physical properties of forest floor layers mean that they have completely different combustion properties and are treated as a separate components in forest fire studies. The $L$ layer, because of its low BD and direct contact with the atmosphere, shows considerable and rapid fluctuations in the moisture content; it dries rapidly, ignites easily and usually burns in the flaming combustion phase. The lower forest floor layers $\mathrm{F}$ and $\mathrm{H}$, usually referred to collectively as "duff", have higher $\mathrm{BD}$, slower drying rates and high mineral content, which dampen fire spread (Van Wagner 1987, Miyanishi 2001, Keane 2015). These layers therefore ignite less easily and burn mostly under smouldering combustion after the main fire front 
has passed. Nevertheless, if sufficiently dry, these layers can also be affected by the flaming combustion phase (Miyanishi 2001, Wilmore 2001, Keane 2015). Duff characteristics primarily influence fire effects (fuel consumption, smoke production, tree mortality, mineral soil exposure, etc.), while L layer characteristics significantly affect fire behaviour (Scott 2012). Based on the purpose of the particular fire management ap plication, a single layer or combination of layers is used.

FFF loading is measured most accurately through destructive sampling, but this is unsuitable for operational management because it is expensive and requires timeconsuming field procedures as well as oven-drying in the laboratory. Alternatively, forest floor loading can be estimated from depth measurements and published $B D$ values for a given forest type, or from regression equations that relate FFF load to depth. Regression equations have been developed for numerous North American species, mostly conifers (Harrington 1986, Van Wagtendonk et al. 1998, DiMario et al. 2018), but not for European black pine (Pinus nigra J.F. Arnold), one of the most widespread conifer species that extends over more than 3.5 million hectares from western North Africa, through southern Europe to Asia Minor (Isajev et al. 2004).

In forests of pine (Pinus) species, the depth and load of the litter (L) layer remain relatively constant over the entire age range, while the depth and load of $\mathrm{F}$ and $\mathrm{H}$ layers increase significantly with age, and therefore so do carbon stocks (Van Wagtendonk et al. 1998, Zhao et al. 2014, Bakšić
\& Bakšić 2017). In contrast, the average bulk densities of individual layers usually do not change significantly with stand age (Hille \& Ouden 2005, Bakšić \& Bakšić 2017).

This study aims to: (i) quantify physical properties (depth, fuel load, BD) and organic carbon (OC) concentrations of black pine forest floor layers and examine how these properties differ with stand age and the layers; (ii) develop regression equations that can be used to convert forest floor depth to load and carbon stock in each layer individually and across all layers; and (iii) evaluate which approach provides more accurate estimates of FFF loads and forest floor carbon (FFC) stocks.

\section{Material and methods}

\section{Study site}

We carried out these analyses in endemic Dalmatian black pine (Pinus nigra J.F. Arnold subsp. dalmatica [Vis.] Franco), which we refer to henceforth simply as black pine, which grows on the upper regions of the Biokovo mountain in Croatia, on the islands of Brač, Hvar and Korčula as well as on the Pelješac peninsula. This is one of the six main subspecies of black pine, of which the others are nigra, salzmannii, pallasiana, mauretanica and laricio (Isajev et al. 2004). These forests grow above the Aleppo pine forests at altitudes of $450-750 \mathrm{~m}$ a.s.l. on islands and above $800 \mathrm{~m}$ a.s.l. on the coast.

A black pine forest on the south Adriatic island of Brač, Croatia was selected for sampling. Black pine forests extend over 1240 ha on Brač and cover most of the plateau on the island (Croatian Forests Ltd
Fig. 1 - Photographs showing forest floor layers in old black pine forest: (L): litter; (F1): upper fermentation

layer; (F2): lower fermentation layer; $(\mathrm{H})$ : humus layer. The smaller image at the upper right shows examples of (FWD): fine woody debris; (B): bark; (C) cones.

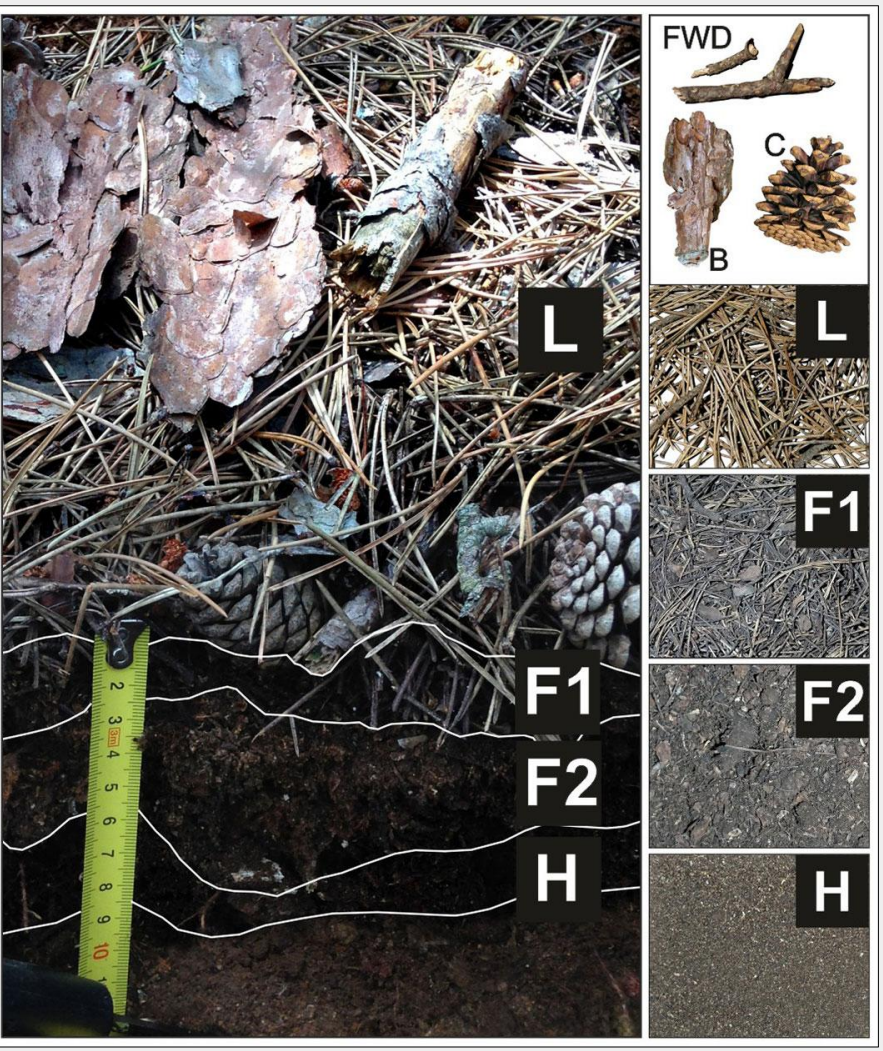

2017). The terrain is predominantly flat or gently sloping, with an average slope of $3.2^{\circ}$.

According to the Köppen classification, the climate is warm-summer Mediterranean (Csb), with a mean annual temperature of $12-13{ }^{\circ} \mathrm{C}$ and mean annual precipitation of 1200-1300 mm based on data for the period 1961-1990 (Zaninović et al. 2008). The forest floor was sampled in the middle of fire season in late July 2015 at three forest stands: (i) young - 40 years $\left(43^{\circ} 17^{\prime}\right.$ $30.15^{\prime \prime} \mathrm{N} ; 16^{\circ} 35^{\prime} 26.6^{\prime \prime} \mathrm{E}$; altitude $630 \mathrm{~m}$ a.s.I.); (ii) mature - 80 years ( $43^{\circ} 17^{\prime} 29.1^{\prime \prime} \mathrm{N}$; $16^{\circ} 35^{\prime} 25.1^{\prime \prime} \mathrm{E}$; altitude $630 \mathrm{~m}$ a.s.l.); and (iii) old uneven-aged - $100-150$ years ( $43^{\circ} 17^{\prime} 1.7^{\prime \prime}$ $\mathrm{N} ; 16^{\circ} 36^{\prime} 48.2^{\prime \prime} \mathrm{E}$, altitude $710 \mathrm{~m}$ a.s.l.). The stands were approximately $3 \mathrm{~km}$ apart and therefore influenced by the same climatic conditions. The dominant soil type in the area is Leptic Cambisol (Humic, Eutric), which alternates with Mollic Leptosol over carbonate parent material (limestone alternating with dolomite). Records indicate no silvicultural treatments or disturbances at the three stands since 1995.

\section{Field sampling}

At each forest stand, 10 samples of forest floor (down to mineral soil) were collected on sites that were flat or gently sloping (up to $5^{\circ}$ ) using destructive sampling. In the old forest stand, the forest floor was sampled near the oldest trees in order to capture the entire range of forest floor properties. At all stands, a $30 \times 30 \mathrm{~cm}$ frame was used to collect the various layers of forest floor below the tree crowns. Individual samples were located at least $10 \mathrm{~m}$ away from one another to reduce risk of spatial autocorrelation of forest floor characteristics (Kreye et al. 2014). A total of 30 samples of each layer L, F1, F2 and $\mathrm{H}$ (Fig. 1) were collected as described in Schulp et al. (2008). Fine woody debris (FWD, $0.6-2.5 \mathrm{~cm}$ in diameter), bark and cones on the surface of the $L$ layer were collected and weighed separately. In each forest floor sample, the depth of an individual layer was taken to be the average at the midpoint on all four sides of the sampling frame. If certain layers showed depth heterogeneity, such as the $\mathrm{F} 2$ and $\mathrm{H}$ layers in Fig. 1, three depths were measured on all four sides and averaged to give the final depth.

Separate sampling using $15 \times 15 \mathrm{~cm}$ frames was performed to determine FFC stock. At each forest stand, 5 samples were taken of each of the layers L, F1, F2 and $\mathrm{H}$.

\section{Laboratory analyses}

Samples were oven-dried in the laboratory for $48 \mathrm{~h}$ at $100{ }^{\circ} \mathrm{C}$ and weighed to the nearest $0.01 \mathrm{~g}$. Forest floor layer depths were combined with the frame dimensions to calculate sample volumes for each layer separately (L, F1, F2 and H). The oven-dried mass of each forest floor layer sample was divided by the sample volume to calculate BD. Mean BD were calculated for each forest floor layer. FFF load was calculated for 
each sample as the sum of layer loads and was expressed as a dry mass per unit area $\left(\mathrm{Mg} \mathrm{ha}^{-1}\right)$. Mean FFF load was calculated by layer and across all layers at each forest stand. Mean FWD, bark and cone loads were also determined at each forest stand.

All samples for organic carbon (OC) concentration determination were dried at 40 ${ }^{\circ} \mathrm{C}$, ground using a cutting mill (Retsch SM $100^{\oplus}$, Haan, Germany) and sieved through a 2-mm sieve. The mass of the prepared samples ranged from about $20 \mathrm{~g}$ for the $L$ layer up to $200 \mathrm{~g}$ for $\mathrm{F} 2$ and $\mathrm{H}$ layers or $500 \mathrm{~g}$ for FWD, bark and cones. OC concentration was determined for each forest floor layer and for FWD, bark and cones according to the ISO-10694 (1995) procedure using a Flash $2000^{\circledast}$ NC Soil elemental analyser (Thermo Fisher Scientific, Milan, Italy). FFC stocks were calculated by multiplying $O C$ concentration with FFF loads for each forest floor layer, which were then combined into a total FFC stock expressed as a mass of carbon per unit area ( $\mathrm{MgC} \mathrm{ha-1})$.

\section{Data analyses}

Differences in depths, BD, FFF loads and FFC stocks between the same forest floor layers in different forest stands were assessed using one-way ANOVA. Alternatively, if Levene's test for homogeneity of variances was statistically significant, then the non-parametric Kruskal-Wallis $\mathrm{H}$ test was used. For all statistical tests, a level of $5 \%$ was considered as significant.

Regression analysis was used to explore relationships between forest floor depth and associated loads and carbon stocks, for all layers at each forest stand, as well as separately for the layers $\mathrm{L}$ and $\mathrm{F}+\mathrm{H}$ (as duff). The quality of the resulting regression equations $(p<0.001)$ was assessed using the, mean bias error (MBE), mean absolute error (MAE), root mean square error (RMSE) and coefficient of determination $\left(R^{2}\right)$. Statistical analysis was performed using Microsoft Excel ${ }^{\circledR}$ and Statistica ${ }^{\circledR}$ v. 8.0 (StatSoft, Tulsa, OK, USA).

\section{Results}

Forest floor depth and bulk density

Forest floor depths at the black pine forest stands in this study ranged from 1.5 to $11.5 \mathrm{~cm}$. Average overall forest floor depth increased with stand age: it measured $2.5 \pm$ $0.5 \mathrm{~cm}$ (mean \pm standard deviation, SD) at the young stand, $3.8 \pm 1.5 \mathrm{~cm}$ at the mature stand, and $5.9 \pm 2.9 \mathrm{~cm}$ at the old stand (Fig. 2). The depths of the $L$ and F1 layers did not vary substantially with age, whereas the depths of the $\mathrm{F} 2$ and $\mathrm{H}$ layers increased with age. F2 depth across the three stands was $0.4 \pm 0.3 \mathrm{~cm}, 1.1 \pm 0.4 \mathrm{~cm}$ and $2.2 \pm 1.4 \mathrm{~cm}$; the value at the old stand was significantly greater than at the other two stands $\left(\mathrm{H}_{[2]}=14.392 ; \mathrm{p}<0.001 ; \mathrm{N}=30\right) . \mathrm{H}$ depth was $0.2 \pm 0.2 \mathrm{~cm}, 0.9 \pm 0.6 \mathrm{~cm}$ and $1.5 \pm 1.4 \mathrm{~cm}$; the latter two values were significantly greater than at the young stand $\left(H_{[2]}=14.933 ; p<0.001 ; N=30-\right.$ Fig. 2$)$.

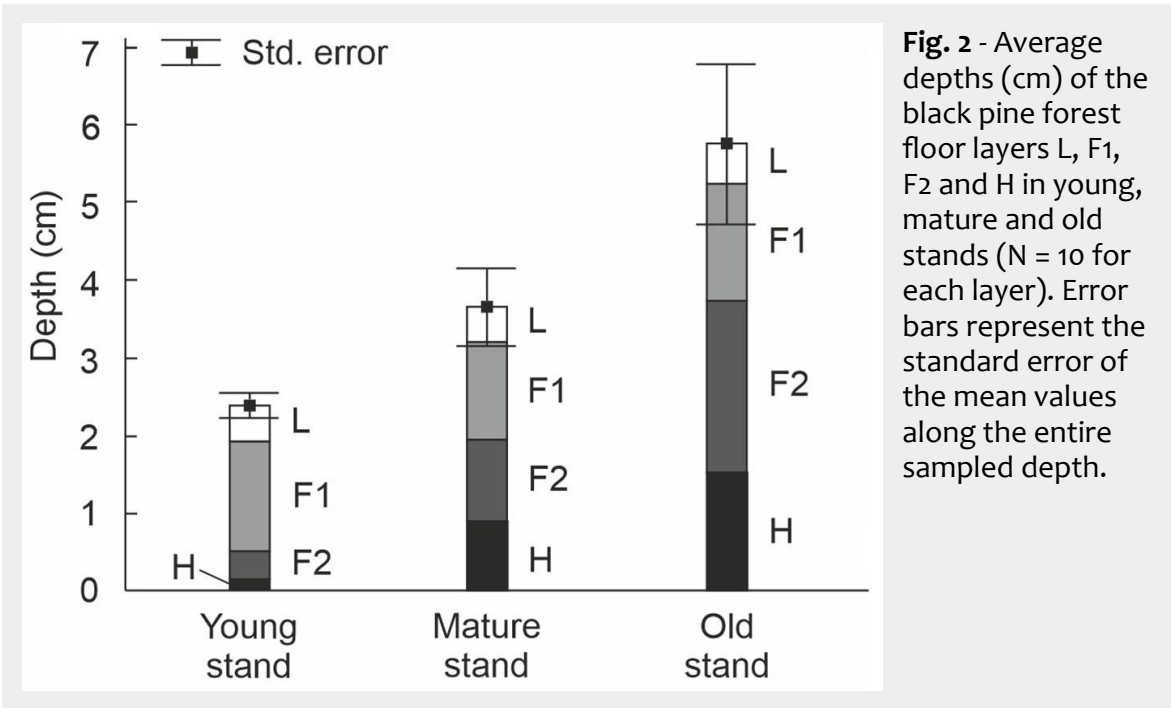

$B D$ of the forest floor increased with 30). Average BD for the entire forest floor depth: the $L$ layer was less compacted than was $132.2 \pm 81.3 \mathrm{~kg} \mathrm{~m}^{-3}$. the $\mathrm{F} 1$ and $\mathrm{F} 2$ layers, and the $\mathrm{H}$ layer was the densest (Tab. 1). BD in the F1 layer was

significantly higher in the old stand than in FFF loads in our study increased with the young stand $\left(\mathrm{H}_{[2]}=8.286 ; \mathrm{p}=0.016 ; \mathrm{N}=\right.$ stand age (Tab. 2$)$. FFF load in the $\mathrm{F} 1$ layer

Tab. 1 - Bulk density values per forest floor layers L, F1, F2 and H. Different letters indicate significant differences among forest stands for the F1 layer, based on the KruskalWallis test. (SD): standard deviation; (CV): coefficient of variation.

\begin{tabular}{|c|c|c|c|c|c|c|c|c|}
\hline Forest stand & $N$ & Layer & $\begin{array}{c}\text { Mean } \\
\left(\mathrm{kg} \mathrm{m}^{-3}\right)\end{array}$ & $\begin{array}{l}\text { Median } \\
\left(\mathrm{kg} \mathrm{m}^{-3}\right)\end{array}$ & $\begin{array}{c}\text { Min } \\
\left(\mathrm{kg} \mathrm{m}^{-3}\right)\end{array}$ & $\begin{array}{c}\operatorname{Max} \\
\left(\mathrm{kg} \mathrm{m}^{-3}\right)\end{array}$ & $\begin{array}{c}\text { SD } \\
\left(\mathrm{kg} \mathrm{m}^{-3}\right)\end{array}$ & $\begin{array}{l}\mathrm{CV} \\
(\%)\end{array}$ \\
\hline \multirow{2}{*}{ All stands } & 30 & $L$ & 29.6 & 26.4 & 14.8 & 50.8 & 10.1 & 34 \\
\hline & 30 & F1 & 111.0 & 107.8 & 61.1 & 198.1 & 33.0 & 30 \\
\hline Young stand & 10 & \multirow{3}{*}{ F1 } & $93.9 \mathrm{a}$ & 91.9 & 61.1 & 159.8 & 29.5 & 31 \\
\hline Mature stand & 10 & & $103.2 \mathrm{ab}$ & 102.8 & 83.9 & 125.3 & 13.9 & 13 \\
\hline Old stand & 10 & & $136.0 \mathrm{~b}$ & 123.1 & 83.2 & 198.1 & 36.9 & 27 \\
\hline \multirow{2}{*}{ All stands } & 25 & F2 & 160.5 & 159.4 & 72.9 & 245.4 & 43.9 & 27 \\
\hline & 28 & $\mathrm{H}$ & 227.6 & 223.8 & 137.6 & 359.3 & 47.3 & 21 \\
\hline
\end{tabular}

Tab. 2 - FFF loads, OC concentrations and FFC stocks by layers L, F1, F2, H and in total (all layer loads per sample) for young, mature and old black pine forest stands ( $N=10$ for each layer). (SD): standard deviation; (CV): coefficient of variation.

\begin{tabular}{|c|c|c|c|c|c|c|c|c|c|}
\hline \multirow{2}{*}{ 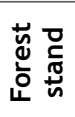 } & \multirow{2}{*}{ ঠ্ঠ } & \multicolumn{6}{|c|}{ FFF load } & \multirow{2}{*}{$-\begin{array}{c}O C \\
\left(\mathrm{~g} \mathrm{~kg}^{-1}\right)\end{array}$} & \multirow{2}{*}{$\begin{array}{c}\text { Mean FFC } \\
\text { stock } \\
\left(\mathrm{Mg} \mathrm{Cha}^{-1}\right)\end{array}$} \\
\hline & & $\begin{array}{c}\text { Mean } \\
\left(\mathrm{Mg} \mathrm{ha}^{-1}\right)\end{array}$ & $\begin{array}{l}\text { Median } \\
\left(\text { Mg ha }^{-1}\right)\end{array}$ & $\begin{array}{c}\text { Min } \\
\left(\mathrm{Mg} \mathrm{ha}^{-1}\right)\end{array}$ & $\begin{array}{c}\operatorname{Max} \\
\left(\mathrm{Mg} \mathrm{ha}^{-1}\right)\end{array}$ & $\begin{array}{c}\text { SD } \\
\left(M_{g} h^{-1}\right)\end{array}$ & $\begin{array}{l}\text { CV } \\
\text { (\%) }\end{array}$ & & \\
\hline \multirow{5}{*}{ 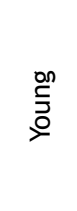 } & L & 2.057 & 1.899 & 1.130 & 3.492 & 0.66 & 32 & 538 & 1.107 \\
\hline & F1 & 13.283 & 12.264 & 9.172 & 20.778 & 3.87 & 29 & 537 & 7.133 \\
\hline & F2 & 6.031 & 6.306 & 0 & 16.962 & 4.68 & 78 & 459 & 2.768 \\
\hline & $\mathrm{H}$ & 3.991 & 2.332 & 0 & 14.931 & 4.48 & 112 & 397 & 1.585 \\
\hline & Total & 25.362 & 23.539 & 11.859 & 47.085 & 10.31 & 41 & - & 12.593 \\
\hline \multirow{5}{*}{$\begin{array}{l}\frac{0}{3} \\
\frac{\pi}{2} \\
\sum\end{array}$} & L & 1.291 & 1.257 & 0.738 & 2.628 & 0.54 & 42 & 538 & 0.695 \\
\hline & $\mathrm{F} 1$ & 13.152 & 12.562 & 7.804 & 19.394 & 3.55 & 27 & 537 & 7.063 \\
\hline & F2 & 9.857 & 8.690 & 0 & 28.024 & 10.02 & 102 & 459 & 4.524 \\
\hline & $\mathrm{H}$ & 19.620 & 18.553 & 0 & 35.220 & 12.19 & 62 & 397 & 7.789 \\
\hline & Total & 43.920 & 42.226 & 14.292 & 77.244 & 22.91 & 52 & - & 20.071 \\
\hline \multirow{5}{*}{ 믐 } & L & 1.249 & 1.196 & 0.648 & 1.930 & 0.41 & 33 & 538 & 0.672 \\
\hline & F1 & 20.424 & 20.191 & 10.290 & 30.170 & 6.57 & 32 & 537 & 10.968 \\
\hline & F2 & 41.318 & 27.516 & 15.939 & 92.450 & 27.18 & 66 & 459 & 18.965 \\
\hline & $\mathrm{H}$ & 32.909 & 18.976 & 13.383 & 104.749 & 28.67 & 87 & 397 & 13.065 \\
\hline & Total & 95.900 & 81.838 & 46.248 & 197.347 & 51.65 & 54 & - & 43.670 \\
\hline
\end{tabular}




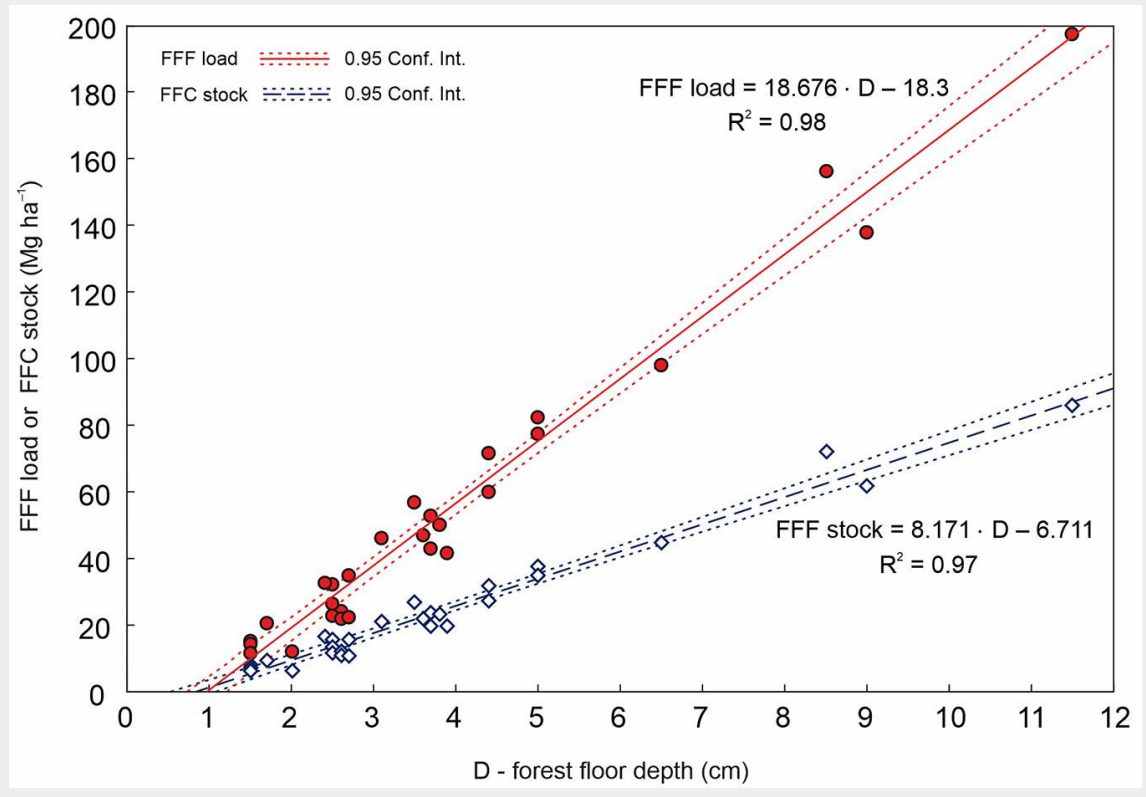

Fig. 3 - Regression equations for estimating FFF loads and FFC stocks as a function of forest floor depth at depths of $1.5-11.5 \mathrm{~cm}$. The thin dashed lines around the thicker lines indicate the $95 \%$ confidence interval (Conf. Int.).

Tab. 3 - Fine woody debris (0.6-2.5 cm in diameter), bark and cone loads, and their OC concentrations and $\mathrm{C}$ stocks in young, mature and old black pine forest stands $(\mathrm{N}=$ 10). (FWD): Fine woody debris; (B): bark and (C): cone.

\begin{tabular}{|c|c|c|c|c|c|c|c|c|c|}
\hline 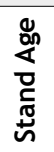 & 告 & $\begin{array}{c}\text { Mean } \\
\left(\mathrm{Mg} \mathrm{ha}^{-1}\right)\end{array}$ & $\begin{array}{l}\text { Median } \\
\left(\mathrm{Mg} \mathrm{ha}^{-1}\right)\end{array}$ & $\underset{\left(\mathrm{Mg} \mathrm{ha}^{-1}\right)}{\operatorname{Min}}$ & $\begin{array}{c}\operatorname{Max} \\
\left(\mathrm{Mg} \mathrm{ha}^{-1}\right)\end{array}$ & $\begin{array}{c}\text { SD } \\
\left(\mathrm{Mg} \mathrm{ha}^{-1}\right)\end{array}$ & $\begin{array}{l}\text { CV } \\
\text { (\%) }\end{array}$ & $\underset{\left(\mathrm{g} \mathrm{kg}^{-1}\right)}{\mathrm{OC}}$ & $\begin{array}{c}\text { Mean C } \\
\text { stock } \\
\left(\mathrm{Mg} \mathrm{C} \mathrm{ha-1}^{-1}\right)\end{array}$ \\
\hline \multirow{4}{*}{$\begin{array}{l}\stackrel{\text { on }}{5} \\
\text { ટ⿱ }\end{array}$} & FWD & 1.238 & 0.630 & 0 & 4.402 & 1.50 & 121 & 534 & 0.661 \\
\hline & B & 0.084 & 0.000 & 0 & 0.297 & 0.14 & 161 & 530 & 0.045 \\
\hline & $C$ & 0.720 & 0.882 & 0 & 1.716 & 0.68 & 94 & 539 & 0.388 \\
\hline & Total & 2.043 & 1.165 & 0.733 & 5.156 & 1.67 & 82 & - & 1.094 \\
\hline \multirow{4}{*}{ 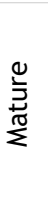 } & FWD & 1.938 & 0.399 & 0 & 9.130 & 3.41 & 176 & 534 & 1.035 \\
\hline & B & 0.255 & 0.119 & 0 & 0.818 & 0.30 & 119 & 530 & 0.135 \\
\hline & $C$ & 5.492 & 4.367 & 0 & 13.777 & 5.04 & 92 & 539 & 2.960 \\
\hline & Total & 7.685 & 4.367 & 0.738 & 22.392 & 8.13 & 106 & - & 4.130 \\
\hline \multirow{4}{*}{$\frac{0}{0}$} & FWD & 3.424 & 3.571 & 0.626 & 6.602 & 2.27 & 66 & 534 & 1.828 \\
\hline & B & 0.764 & 0.451 & 0 & 3.064 & 0.91 & 119 & 530 & 0.405 \\
\hline & $C$ & 12.114 & 11.661 & 4.473 & 22.566 & 5.74 & 47 & 539 & 6.529 \\
\hline & Total & 16.302 & 17.274 & 8.028 & 23.702 & 5.66 & 35 & - & 8.763 \\
\hline
\end{tabular}

was significantly higher in the old stand than in the other two stands $(\mathrm{F}=7.334$; $\mathrm{p}<0.003)$, as was as the $\mathrm{F} 2$ layer $\left(\mathrm{H}_{[2]}=\right.$ 15.429; $\mathrm{p}<0.001 ; \mathrm{N}=30$ ). FFF load in the $\mathrm{H}$ layer was significantly higher in mature and old stands than in the young stand $\left(\mathrm{H}_{[2]}=\right.$ 14.777; $\mathrm{p}<0.001 ; \mathrm{N}=30$ ). The $\mathrm{F} 2$ and $\mathrm{H}$ layers showed greater variation in loads than the $\mathrm{L}$ and $\mathrm{F} 1$ layers in all stands. Depth, FFF load and FFC stock in the $\mathrm{H}$ layer correlated with the corresponding parameters in the F2 layer, with respective correlation coefficients $(r)$ of $0.76,0.68,0.68$ (all $p<0.01$ ).

Loads of FWD, bark and cones also increased with stand age and generally showed higher coefficients of variation than forest floor layers (Tab. 3).

\section{Organic carbon concentrations and carbon stocks}

To estimate FFC stocks more accurately, OC concentrations were determined separately for each forest floor layer and separately for FWD, bark and cones. Average OC concentrations (mean \pm SD) were significantly higher in the L layer ( $538 \pm 6 \mathrm{~g}$ $\left.\mathrm{kg}^{-1}\right)$ and $\mathrm{F}_{1}$ layer $\left(537 \pm 7 \mathrm{~g} \mathrm{~kg}^{-1}\right)$ than in the F2 layer (459 $\left.\pm 40 \mathrm{~g} \mathrm{~kg}^{-1}\right)$ and $\mathrm{H}$ layer (397 \pm $\left.44 \mathrm{~g} \mathrm{~kg}^{-1}\right)\left(\mathrm{H}_{[3]}=47.034 ; \mathrm{p}<0.001 ; \mathrm{N}=60-\right.$ Tab. 2). OC concentrations in FWD (534 \pm 7 $\left.\mathrm{g} \mathrm{kg}^{-1}\right)$, bark $\left(530 \pm 13.5 \mathrm{~g} \mathrm{~kg}^{-1}\right)$ and cones $\left(539 \pm 8 \mathrm{~g} \mathrm{~kg}^{-1}\right)$ were similar to those in the $\mathrm{L}$ and $\mathrm{F} 1$ layers (Tab. 3). OC concentrations were used to calculate carbon stocks for each layer separately. FFC stock ranged from 6.4 Mg ha-1 in the young stand to 85.8 $\mathrm{Mg} \mathrm{C} \mathrm{ha-1} \mathrm{in} \mathrm{the} \mathrm{old} \mathrm{stand.} \mathrm{Since} \mathrm{carbon}$ stocks depend on loads, they showed the same relationship with age as FFF loads did. The old stand showed significantly higher carbon stocks than the other two stands in the $\mathrm{F} 1$ layer $\left(\mathrm{H}_{[2]}=8.454 ; \mathrm{p}=\right.$ $0.015 ; \mathrm{N}=30)$ and $\mathrm{F} 2$ layer $\left(\mathrm{H}_{[2]}=15.429 ; \mathrm{p}<\right.$ $0.001 ; \mathrm{N}=30$ ). The mature and old stands showed significantly higher carbon stock than the young stand in the $\mathrm{H}$ layer $\left(\mathrm{H}_{[2]}=\right.$ 14.777; $\mathrm{p}<0.001 ; \mathrm{N}=30$ ). Average $\mathrm{OC}$ concentration for the entire forest floor was $483 \pm 67 \mathrm{~g} \mathrm{~kg}^{-1}$.

\section{Estimating FFF loads and FFC stocks}

Simple linear regression of FFF loads and FFC stocks was performed for the $L$ layer

Tab. 4 - Regression equations for estimating FFF loads and FFC stocks as a function of forest floor depth (ranging from $1.5 \mathrm{~cm}$ to 11.5 $\mathrm{cm}$ ). (LF load): litter fuel load ( $\left.\mathrm{Mg} \mathrm{ha}^{-1}\right)$; ( $\left(\mathrm{LC}\right.$ stock): litter carbon stock ( $\left.\mathrm{Mg} \mathrm{ha}^{-1}\right)$; (FHF load): fuel load in $\mathrm{F}$ and $\mathrm{H}$ layers ( $\mathrm{Mg}^{-1}$ ); ( $\mathrm{FHC}$ stock): carbon stock in F and $\mathrm{H}$ layers (Mg ha-1); (FFF load): forest floor fuel load (Mg ha-1); (FFC stock): forest floor carbon stock (Mg ha-1); (D): forest floor depth (cm); (MBE): mean bias error; (MAE): mean absolute error; (RMSE): root mean square error; $\left(R^{2}\right)$ : coefficient of determination; $\left(\mathrm{SE}_{\mathrm{x}}\right)$ : standard error of the regression coefficient; $\left(\mathrm{SE}_{\mathrm{i}}\right)$ : standard error of the intercept.

\begin{tabular}{llccccccc}
\hline \multirow{2}{*}{ No } & \multirow{2}{*}{ Regression equations } & \multicolumn{5}{c}{ Statistical parameters } \\
\cline { 3 - 8 } & & $\mathrm{SE}_{\mathrm{x}}$ & $\mathrm{SE}_{\mathrm{i}}$ & $\mathbf{p}$ & $\mathrm{MBE}$ & $\mathrm{MAE}$ & $\mathrm{RMSE}$ & $\mathbf{R}^{2}$ \\
\hline 1 & LF load $=2.986 \cdot \mathrm{D}$ & 0.195 & - & $<0.001$ & -0.024 & 0.409 & 0.527 & 0.38 \\
\hline 2 & LC stock $=1.597 \cdot \mathrm{D}$ & 0.108 & - & $<0.001$ & -0.014 & 0.238 & 0.297 & 0.38 \\
\hline 3 & FHF load $=19.145 \cdot \mathrm{D}-11.774$ & 0.531 & 2.124 & $<0.001$ & -0.001 & 5.171 & 6.287 & 0.98 \\
\hline 4 & FHC stock $=8.378 \cdot \mathrm{D}-3.985$ & 0.270 & 1.099 & $<0.001$ & -0.001 & 2.542 & 3.185 & 0.97 \\
\hline 5 & FFF load $=18.676 \cdot \mathrm{D}-18.3$ & 0.585 & 2.650 & $<0.001$ & 0.001 & 5.640 & 6.795 & 0.98 \\
\hline 6 & FFC stock $=8.171 \cdot \mathrm{D}-6.711$ & 0.276 & 1.251 & $<0.001$ & 0.161 & 2.827 & 3.420 & 0.97 \\
\hline
\end{tabular}


Fig. 4 - Residual values for FFF loads and FFC stocks estimated either using BD and $O C$ concentrations per forest floor layer (red circles), or using mean $\mathrm{BD}$ and mean OC concentration for the entire forest floor (blue diamonds).

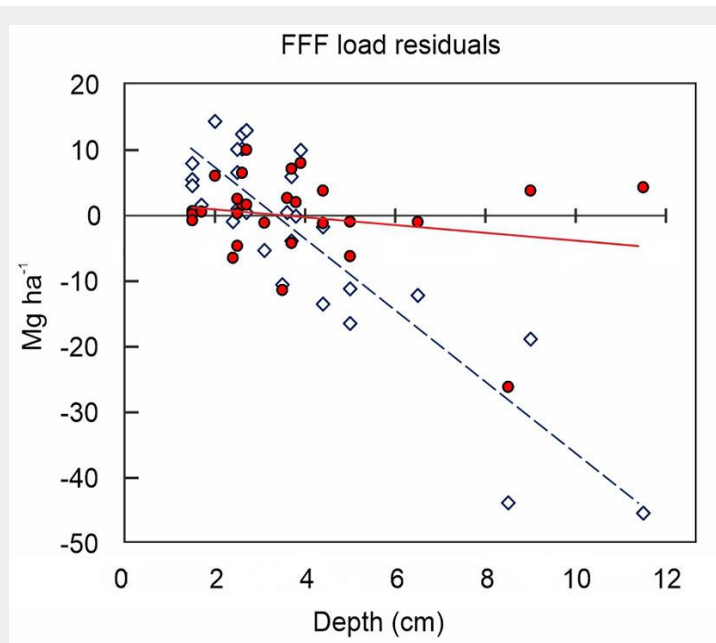

(regression equations no. 1 and 2 - Tab. 4) or for the $\mathrm{F}\left(\mathrm{F}_{1}+\mathrm{F}_{2}\right)$ and $\mathrm{H}$ layers together (regression equations no. 3 and $4-$ Tab. 4 ), or for the entire forest floor (regression equations no. 5 and 6 - Tab. 4, Fig. 3). When the forest floor was deeper than 1.5 $\mathrm{cm}$, regression-based estimates of FFF loads and FFC stocks for the entire forest floor were similar to the sum of separate estimates for the $\mathrm{L}$ layer and $\mathrm{F}+\mathrm{H}$ layers. When the floor was shallower than $1.5 \mathrm{~cm}$, regressions did not generate reasonable estimates for $\mathrm{F}+\mathrm{H}$ layers or for the entire forest floor. The $y$-intercept in our regression models was negative, leading to underestimates of FFF loads and FFC stocks.

Tab. S1 (Supplementary material) provides FFF loads and FFC stocks calculated using $\mathrm{BD}$ and $\mathrm{OC}$ concentrations per forest floor layer (equations no. 1 and 2 - Tab. S1), or calculated using mean BD (132.2 $\left.\mathrm{kg} \mathrm{m}^{-3}\right)$ and $\mathrm{OC}$ concentration (483 $\left.\mathrm{g} \mathrm{kg}^{-1}\right)$ for the entire forest floor (equations no. 3 and $4-$ Tab. S1). According to statistical parameters (Tab. S1 in Supplementary material) estimates of FFF load and FFC stock based on $\mathrm{BD}$ and $\mathrm{OC}$ concentrations per forest floor layer were more accurate than those based on regression equations, and far more accurate than those based on BD and OC concentration for the entire forest floor (Fig. 4).

\section{Discussion}

Our study suggests that Dalmatian black pine forests contain substantial FFF loads and FFC stocks (Tab. 2). Compared to the young stand in our study, FFF load was 1.7 times higher in the mature stand and 3.8 times higher in the old stand, while FFC stock was 1.6 and 3.5 times higher, respectively. The age-dependent increases in FFF load and FFC stock were not identical because decomposing materials accumulate in the $\mathrm{F}_{2}$ and $\mathrm{H}$ layers, which have significantly lower OC concentration, in turn affecting the total FFC stock. Stand age did not significantly affect FFF load or FFC stock in the litter layer (excluding FWD, bark or cones). The $F_{1}$ and $F_{2}$ layers showed significantly higher loads at the old forest stand than at the young and mature stands, reflecting larger amounts of woody fuel particles, bark and especially cones in the old stand. These heavier particles substantially increase BD. Indeed, the load of FWD, bark and cones in the old stand was 16.3 $\mathrm{Mg} \mathrm{ha}^{-1}$ (74\% of which was due to cones), which is much higher than in young and mature stands (Tab. 3). Increasing cone abundance on the forest floor can facilitate ignition of intermixed forest floor fuels, leading to taller flame heights and longer flaming duration (Kreye et al. 2013). The survival of large, mature black pine trees is essential for successful post-fire regeneration as they serve as seed sources (Christopoulou et al. 2014). During periods of hot and dry weather, accumulated large amounts of forest floor (as reflected in our old stands - Tab. 2) significantly increase the potential for high severity wildfires and exacerbate their effects on forest ecosystems. Fuel reduction treatments such as thinning, raking, and controlled burning should be considered at these stands in order to reduce fire hazard by reducing fuel loading. The high value of these trees in endemic black pine forests is reflected in their status as a priority habitat under the EU Habitats Directive (Zaghi 2008).

Since we were unable to find closely related studies, we can make only general comparisons with studies of other European black pine. In doing so, we emphasize that inter-study comparisons of FFF loads and FFC stocks are not straightforward due to the many sources of variability, including sampling and analytical methods (Schulp et al. 2008, Keane et al. 2012, Kreye et al. 2014). FFF loads at the young black pine stand in our study are comparable to those reported at low site quality stands in Greece (Kavvadias et al. 2001), while the FFF loads at the mature stand in our study are comparable to those reported in Greece (Papaioannou 2015) and Portugal (Fonseca \& De Figueiredo 2018). Considering similar FFF loads and OC concentration in forest floor layers, FFC stocks at our young stand are comparable to those of black pine plantations in Spain (Herrero et al. 2016), while FFC stocks at our mature stand are comparable to those in Portugal (Fonseca \& De Figueiredo 2018).

We were unable to find published FFF loads for old black pine forests that we could compare with our results, though we can compare our measurements to those that we obtained, using the same methods, in Aleppo pine stands (Bakšić \& Bakšić 2017). Black pine forests occur above Aleppo pine forests in coastal areas. Although the two types of pines showed similar average FFF loads and FFC stocks within the same age classes, BD was significantly higher for black pine and therefore so was FFF load at a given depth. In fact, black pine showed higher $O C$ concentration in the $\mathrm{L}$ layer (by $0.8 \%$ ), $\mathrm{F}$ layer (by $9 \%$ ) and $\mathrm{H}$ layer (by $5 \%$ ).

The coefficients of variation for FFF load in this study ranged from 27 to $112 \%$, similar to variation observed in other studies (Schulp et al. 2008, De Groot et al. 2009, Letang \& De Groot 2012, Keane et al. 2012, Lydersen et al. 2015, Prichard et al. 2017).

The results in Tab. S1 and Fig. 4 support the idea that separating forest floor layers improves estimation of FFF loads and FFC stocks, reflecting inter-layer differences in $\mathrm{BD}$ and $\mathrm{OC}$ concentration (Brown et al. 1982, Smith \& Heath 2002, Schulp et al. 2008, Chojnacky et al. 2009). Our observation of increasing BD with forest floor depth has also been reported by studies examining litter and duff separately (Van Wagtendonk et al. 1998), each forest floor layer separately (Banwell \& Varner 2014, DiMario et al. 2018), or forest floor strata (Stephens et al. 2004). Forest floor densities that we measured here for black pine are quite similar to those reported for coniferous species for each of the individual layers $\left(L=17.9 \mathrm{~kg} \mathrm{~m}^{-3} ; \mathrm{F}_{1}=118.3 \mathrm{~kg} \mathrm{~m}^{-3} ; \mathrm{F}_{2}=\right.$ $203.4 \mathrm{~kg} \mathrm{~m}^{-3} ; \mathrm{H}=232.5 \mathrm{~kg}^{-3}$ - Schulp et al. 2008).

Our layer-based analysis showed that average $O C$ concentrations were significantly higher in $\mathrm{L}$ and $\mathrm{F} 1$ layers than in $\mathrm{F} 2$ and $\mathrm{H}$ layers. Using layer-specific estimates is likely to be much more accurate than using the default factor of 0.37 for dry forest floor 
mass to C conversion (IPCC 2006, 2019), as proposed by Smith \& Heath (2002) and confirmed by De Vos et al. (2015). Using this IPCC factor in our case of black pine would reduce $\mathrm{FFC}$ stock by $25 \%$ in our young stand and by $19 \%$ in mature and old stands.

Our study provides the first regression equations and $B D$ values (together with $O C$ concentrations) needed for FFF load and FFC stock estimation in Dalmatian black pine.

Simple linear regression is commonly used to convert forest floor depth to FFF load (Harrington 1986, Knapp et al. 2005, Ewell 2006) and C stock (Brown et al. 2004). Indeed, it proved to be the best choice in the present study, giving better BIAS, MAE, and RMSE than quadratic polynomial, cubic polynomial, or power regression equations (not shown). In the end, we selected a simple linear equation with no intercept $(y=0)$ for the $L$ layer (equations no. 1-2 - Tab. 4), whereas we chose a simple linear equation with calculated intercept for the $\mathrm{F}+\mathrm{H}$ layers (equations no. 3-4 Tab. 4) and for the entire forest floor (equations no. 5-6 - Tab. 4). Regression equations are straightforward for estimating total FFF load and FFC stocks and already include the relationship between the depths of individual layers and related loads, as well as the OC concentrations and carbon stocks.

The regression equations derived here can be used for forest floor depths ranging from $1.5 \mathrm{~cm}$ to $11.5 \mathrm{~cm}$. Further work should obtain data for forest floors shallower than $1.5 \mathrm{~cm}$. When the forest floor is shallower than $1.5 \mathrm{~cm}$, we suggest using $B D$ and $O C$ concentrations per forest floor layer to calculate FFF load and FFC stock (equations 1 and 2, respectively - Tab. S1 in Supplementary material). This approach is likely to give more accurate results and can be applied to all forest floor depths. However, this approach is time-consuming because it requires establishing the depth of each forest floor layer, which in turn requires specialized training in forest floor morphology. We advise against estimating FFF loads and FFC stocks using mean BD and OC concentration for the entire forest floor because this approach leads to underestimation that worsens with increasing depth (Fig. 4).

The results presented here are suitable for forest floor fuel mapping and quantification of FFF loads and FFC stocks based on depth. Fuel depth is measured easily, avoiding the need for time-consuming collection, weighing and laboratory analysis of large amounts of forest floor fuels. Spatial distribution of FFF loads and FFC stocks can be assessed simply by measuring forest floor depths. Most fire behaviour and effects models require separate litter and duff inputs so those models can be used with the proposed equations by researchers and fire managers.

Further work should explore the applica- bility of our models to other sub-Mediterranean black pine forests, since even stands of the same species in adjacent forests can differ in forest floor loads and $\mathrm{BD}$ as a result of variation in climate, soil, biomass production, and rates of litter deposition and decomposition (Harrington 1986, Schulp et al. 2008, Keane et al. 2012, Kreye et al. 2014).

\section{Conclusions}

Analysis of FFF loads is important for many forest management applications, especially those related to fire management and carbon balance. Our work suggests that sampling individual layers of the forest floor and determining their OC concentrations leads to more accurate calculations of BD and therefore of FFF loads and FC stocks.

Here we developed regression equations that relate forest floor load in black pine stands to their depth, as well as equations that use BD and depth per layer to quickly estimate FFF load. These equations, together with the OC concentrations determined here for individual forest floor layers, simplify estimations of FFC stocks.

The best estimates of FFF loads and FFC stocks were obtained by using depth, BD and $\mathrm{OC}$ concentrations per layer. The regression equations developed here provide similar estimates as equations that rely on $\mathrm{BD}$ and can be used for forest floor depths ranging from $1.5 \mathrm{~cm}$ to $11.5 \mathrm{~cm}$.

Our results suggest that older, undisturbed stands of black pine have particularly large FFF loads and FFC stocks. Our approach may be applicable to similar subMediterranean black pine forests, although its generalisability should be verified through site-specific testing.

\section{Acknowledgments}

Funding for this study was provided by the Scientific Research Program of Croatian Forests Ltd. (2011-2015) in the form of a scholarship to NB.

\section{References}

Bakšić N, Bakšić D (2017). Forest floor fuel loads and Carbon stocks in Aleppo pine forests on island of Mljet. Šumarski list 141(5-6): 247-256. doi: 10.31298/sl.141.5-6.3

Baldock JA, Nelson PN (2000). Soil Organic Matter. In: "Handbook of Soil Science" (Sumner ME ed). CRC Press, Boca Raton, USA, pp. B25B84. - doi: 10.1038/194324bo

Banwell EM, Varner JM (2014). Structure and composition of forest floor fuels in long-unburned Jeffrey pine-white fir forests of the Lake Tahoe Basin, USA. International Journal of Wildland Fire 23: 363-372. - doi: 10.1071/WF13025 Banwell EM, Varner JM, Knapp EE, Van Kirk RW (2013). Spatial, seasonal, and diel forest floor moisture dynamics in Jeffrey pine-white fir forests of the Lake Tahoe Basin, USA. Forest Ecology and Management 305: 11-20. - doi: 10.1016/j. foreco.2013.05.005

Berg B, McClaugherty C (2014). Plant litter - decomposition, humus formation, carbon seques- tration. Springer Verlag, Berlin-Heidelberg, Germany, pp. 315.

Brown JK, Oberheu RD, Johnston CM (1982). Handbook for inventorying surface fuels and biomass in the interior west. General Technical Report INT-129, USDA Forest Service, Intermountain Forest and Range Experiment Station, Ogden, UT, USA, pp. 48. [online] URL: http://books.google.com/books?id=v3MYtnLtx 6YC

Brown S, Shoch D, Pearson T, Delaney M (2004). Methods for measuring and monitoring forestry carbon projects in California. Winrock International, California Energy Commission. PIER Energy-Related Environmental Research 500: 04-072.F.

Chojnacky D, Amacher D, Gavazzi M (2009). Separating duff and litter for improved mass and carbon estimates. Southern Journal of Applied Forestry 33 (1): 29-34. - doi: 10.1093/sjaf/33.1.29 Christopoulou A, Fyllas NM, Andriopoulos P, Koutsias N, Dimitrakopoulos PG, Arianoutsou $M$ (2014). Post-fire regeneration patterns of $\mathrm{Pi}$ nus nigra in a recently burned area in Mount Taygetos, Southern Greece: the role of unburned forest patches. Forest Ecology and Management 327: 148-156. - doi: 10.1016/j.foreco.2014. 05.006

Croatian Forests Ltd (2017). Management program for the period 1.1.2015-31.12.2024 for Management unit Vidova gora. Book I. Forest Administration Split, Forest Office Bra, Split, Croatia.

De Groot WJ, Pritchard JM, Lynham TJ (2009). Forest floor fuel consumption and carbon emissions in Canadian boreal forest fires. Canadian Journal of Forest Research 39: 367-382. - doi: 10.1139/X08-192

De Groot W (2012). CANFIRE model. Natural Resources Canada, Canadian Forest Service, Great Lakes Forestry Centre, Sault Ste. Marie, Ontario, Frontline Express 62, pp. 2. [online] URL: http://cfs.nrcan.gc.ca/publications?id=34093

De Vos B, Cools N, Ilvesniemi H, Vesterdal L, Vanguelova E, Carnicelli S (2015). Benchmark values for forest soil carbon stocks in Europe: results from a large scale forest soil survey. Geoderma 251-252: 33-36. - doi: 10.1016/j.geoderma.2015. 03.008

DiMario AA, Kane JM, Jules ES (2018). Characterizing forest floor fuels surrounding large sugar pine (Pinus lambertiana) in the Klamath Mountains, California. Northwest Science 92 (3): 181190. - doi: 10.3955/046.092.0305

Ewell CM (2006). Methods and modeling equations to quantify the litter layer of coniferous forests in California National Forests. MS Thesis, Faculty of Humboldt State University, Arcata, CA, USA, pp. 77. [online] URL: http://hdl. handle.net/2148/140

Fonseca F, De Figueiredo T (2018). Carbon and nitrogen in forest floor and mineral soil under four forest species in the Mediterranean region. Spanish Journal of Soil Science 8 (1): 4256. - doi: 10.3232/SJSS.2018.V8.N1.04

Harrington MG (1986). Comparison of forest floor depth to loading relationships from several Arizona ponderosa pine stands. Research Note RM-463, USDA Forest Service, Rocky Mountain and Range Experiment Station, Ogden, Utah, USA, pp. 5. [online] URL: http:// 
books.google.com/books?id=yu21F3FN1roC Herrero C, Turrión MB, Pando V, Bravo F (2016). Carbon content of forest floor and mineral soil in Mediterranean Pinus ssp. and Oak stands in acid soils in Northern Spain. Forest Systems 25 (2): 1-13. - doi: 10.5424/fs/2016252-09149

Hille M, Ouden J (2005). Fuel load, humus consumption and humus moisture dynamics in Central European Scots pine stands. International Journal of Wildland Fire 14: 153-159. - doi: 10.1071/WF04026

Hood SM (2010). Mitigating old tree mortality in long-unburned, fire-dependent forests: a synthesis. General Technical Report RMRS-GTR238, USDA Forest Service, Rocky Mountain Research Station, Fort Collins, CO, USA, pp. 71. [online] URL: http://books.google.com/books? id=Aizv7kID-PoC

IPCC (2006). IPCC guidelines for national greenhouse gas inventories (Eggleston HS, Buendia L, Miwa K, Ngara T, Tanabe K eds). Prepared by the National Greenhouse Gas Inventories Programme. IGES, Japan, pp. A.2.10.

IPCC (2019). 2019 Refinement to the 2006 IPCC guidelines for national greenhouse gas inventories (Calvo Buendia E, Tanabe K, Kranjc A, Baasansuren J, Fukuda $M$, Ngarize $S$, Osako A, Pyrozhenko Y, Shermanau P, Federici S eds). IPCC, Switzerland, pp. 2.23.

Isajev V, Fady B, Semerci $\mathrm{H}$, Andonovski $\mathrm{V}$ (2004). EUFORGEN Technical Guidelines for genetic conservation and use for European black pine (Pinus nigra). International Plant Genetic Resources Institute, Rome, Italy, pp. 6. [online] URL: http://books.google.com/books?id=-QAE8 HTtwIC

ISO-10694 (1995). Soil quality determination of organic and total carbon after dry combustion (elementary analysis). International Organization for Standardization, Geneva, Switzerland, pp. 7. [online] URL: http://www.iso.org/stand ard/18782.html

Kavvadias VA, Alifragis D, Tsiontsis A, Brofas G, Stamatelos $G$ (2001). Litterfall, litter accumulation and litter decomposition rates in four forest ecosystems in northern Greece. Forest Ecology and Management 144: 113-127. - doi: 10.1016/ S0378-1127(00)00365-0

Keane RE, Gray K, Bacciu V (2012). Spatial variability of wildland fuel characteristics in Northern Rocky Mountain ecosystems. Research Paper RMRS-RP-98, USDA Forest Service, Rocky Mountain Research Station, Fort Collins, CO, USA, pp. 56. - doi: 10.2737/RMRS-RP-98

Knapp EE, Keeley JE, Ballenger EA, Brennan TJ (2005). Fuel reduction and coarse woody debris dynamics with early season and late season prescribed fire in a Sierra Nevada mixed conifer forest. Forest Ecology and Management 208: 383-397. - doi: 10.1016/j.foreco.2005.01.016

Keane RE (2015). Wildland fuel fundamentals and applications. Springer International Publishing, Switzerland, pp. 191. - doi: 10.1007/9783-319-09015-3

Kreye JK, Varner JM, Dugaw CJ, Chao J, Szeczei
J, Engber EA (2013). Pine cones facilitate ignition of forest floor duff. Canadian Journal of Forest Research 43: 512-516. - doi: 10.1139/cjfr2013-0019

Kreye JK, Varner JM, Dugaw CJ (2014). Spatial and temporal variability of forest floor duff characteristics in long-unburned Pinus palustris forests. Canadian Journal of Forest Research 44: 1477-1486. - doi: 10.1139/cjfr-2014-0223

Letang DL, De Groot WJ (2012). Forest floor depths and fuel loads in upland Canadian forests. Canadian Journal of Forest Research 42: 1551-1565. - doi: 10.1139/x2012-093

Lydersen JM, Collins BM, Knapp EE, Roller GB, Stephens $S$ (2015). Relating fuel loads to overstorey structure and composition in a fire-excluded Sierra Nevada mixed conifer forest. International Journal of Wildland Fire 24: 484494. - doi: 10.1071/WF13066

Lutes DC (2017). First order fire effects model FOFEM 6.4 - User guide. Fire and Aviation Management, Rocky Mountain Research Station, Fire Modeling Institute, Missoula, MT, USA, pp. 87.

Miyanishi K (2001). Duff consumption. In: "Forest Fires: Behavior and Ecological Effects" (Johnson EA, Miyanishi K eds). Academic Press, New York, USA, pp. 437-475. - doi: 10.1016/B97 8-012386660-8/50015-5

Ottmar R, Andreu A (2007). Litter and duff bulk densities in the Southern United States. Joint Fire Science Program Project \#04-2-1-49, USDA Forest Service, Pacific Northwest Research Station, Seattle, WA, USA, pp. 40. [online] URL: https://www.researchgate.net/publication/2376 18259

Ottmar RD, Sandberg DV, Riccardi CL, Prichard SJ (2007). An overview of the fuel characteristic classification system - Quantifying, classifying, and creating fuelbeds for resource planning. Canadian Journal of Forest Research 37: 2383-2393. - doi: 10.1139/X07-077

Papaioannou AG (2015). Ecological and soil conditions of black pine (Pinus nigra Arn.) stands in the area of the Russian Monastery at Mount Athos. Russian Journal of Ecology 46 (5): 438443. - doi: $10.1134 / S 1067413615050161$

Prichard SJ, Kennedy MC, Wright CS, Cronan JB, Ottmar RD (2017). Predicting forest floor and woody fuel consumption from prescribed burns in southern and western pine ecosystems of the United States. Forest Ecology and Management 405: 328-338. - doi: 10.1016/j.dib.2 017.10.029

Schulp CJE, Nabuurs GJ, Verburg PH, De Waal RW (2008). Effect of tree species on carbon stocks in forest floor and mineral soil and implications for soil carbon inventories. Forest Ecology and Management 256: 482-490. - doi: 10.101 6/j.foreco.2017.09.025

Scott JH (2012). Introduction to wildfire behavior modeling. National Interagency Fuels, Fire, and Vegetation Technology Transfer, Wildland Fire Management RD\&A, pp. 149. [online] URL: http://pyrologix.com/wp-content/uploads/2014/
04/Scott_20121.pdf

Smith JE, Heath LS (2002). A model of forest floor carbon mass for United States forest types. Research Paper NE-722, USDA Forest Service, Northeastern Research Station, Newtown Square, PA, USA, pp. 37. - doi: 10.2737/NERP-722

Stephens SL, Finney MA, Schantz H (2004). Bulk density and fuel loads of ponderosa pine and white fir forest floors: impacts of leaf morphology. Northwest Science 78 (2): 93-100. [online] URL: http://www.cabdirect.org/cabdirect/abstr act $/ 20043105936$

Van Wagner CE (1987). Development and structure of the Canadian Forest Fire Weather Index System. Technical Report no. 35, Canadian Forestry Service, Chalk River, Ontario, Canada, pp. 37. [online] URL: http://citeseerx.ist.psu.edu/ viewdoc/summary?doi=10.1.1.460.3231

Van Wagtendonk JW, Benedict JM, Sydoriak WM (1998). Fuel bed characteristics of Sierra Nevada conifers. The Western Journal of Applied Forestry 13 (3): 73-84. - doi: 10.1093/wjaf/13.3.73 Varner JM (2005). Smoldering fire in long-unburned longleaf pine forests: linking fuels with fire effects. PhD Thesis, Graduate School of the University of Florida, Gainesville, FL, USA, pp. 111. [online] URL: http://www.researchgate.net/ publication/34927343

Wilmore B (2001). Duff moisture dynamics in black spruce feather moss stands and their relation to the Canadian forest fire danger rating system. MS Thesis, University of Alaska, Fairbanks, USA, pp. 105. [online] URL: http://www. frames.gov/documents/catalog/wilmore_2001. pdf

Zaghi D (2008). Management of Natura 2000 habitats. 9530* (Sub)-Mediterranean pine forests with endemic black pines. European Commission, Brussels, Belgium, pp. 23.

Zaninović K, Gajić-Capka M, Perčec Tadić M, Vučetić M, Milković J, Bajić A, Cindrić K, Cvitan L, Katušin Z, Kaučić D, Likso T, Lončar E, Lončar Z, Mihajlović D, Pandić K, Patarčić $M$, Srnec L, Vučetić V (2008). Climate atlas of Croatia 19611990: 1971-2000. Croatian Meteorological and Hydrological Service, Zagreb, pp. 200. [online] URL: http://klima.hr/razno/publikacije/klimatski atlas hrvatske.pdf

Zhao J, Kang F, Wang L, Yu X, Zhao W, Song X, Zhang Y, Chen F, Sun Y, He T, Han H (2014). Patterns of biomass and carbon distribution across a chronosequence of Chinese pine (Pinus tabulaeformis) forests. PLoS One 9 (4): e94966. doi: 10.1371/journal.pone.0094966

\section{Supplementary Material}

Tab. S1 - Equations for estimating FFF loads and FFC stocks based on BD and OC concentrations for separate layers (layer $=\mathrm{L}$, $\mathrm{F} 1, \mathrm{~F} 2$ and $\mathrm{H}$ ) and for the entire forest floor.

Link: Baksic_3184@supplo01.pdf 